\title{
Psychocosmic Analysis of Suicide
}

\author{
Charles Ogundu Nnaji \\ Department of Philosophy and Religions, University of Abuja, Abuja, Nigeria \\ Email: economos34@yahoo.com \\ Received 16 June 2014; accepted 20 March 2015; published 23 March 2015 \\ Copyright (C) 2015 by author and Scientific Research Publishing Inc. \\ This work is licensed under the Creative Commons Attribution International License (CC BY). \\ http://creativecommons.org/licenses/by/4.0/ \\ (c) (i) Open Access
}

\begin{abstract}
Psychocosmic simply means mundane, worldly or social miseries and problems which adversely affect and influence the human psyche (i.e. mind, mentality or behavior) into contemplating or planning dangerous or felonious acts such as murder, suicide, ritual killings or violent crimes. Thus, the study focuses on different causative psychosocial traumatic factors which often preempt self destruction (i.e. suicide) especially highlighting relevant data from varying source materials, which leads this methodology to the research findings that suicide primarily is biogenetically innate and psychosocially predisposed from psycho-structural behaviors responding to environmental correlates, being social structure human debilitating conditions which often defy solutions which predisposes the victim (or patient) to suicidal behavior (Mann and Stanley, 1980).
\end{abstract}

\section{Keywords}

Psychocosmic, Suicide, Misery

\section{General Introduction}

Kant in Hutchins (1960) had stated that those who had hardly experienced human problems are likely going to commit suicide when real problems come calling. Jackson Smith in Ogundu (2000) narrated the story of a girl (psycho structurally) agitated who claimed that her god instructed her to jump into fire for purification, that which seriously and fatally burnt her. Schilder (1964) cited traumatic stress disorders which induce violent and murderous behaviors in stressed and traumatized victims often leading many to outright homicides and suicides. Thomas Noguchi in Ogundu (2000) introduced forensic issues in the investigation of homicidal, suicidal and other cidic cases in investigating murder, manslaughter, matricide, infanticide, genocide and suicides etc. Psychosocial traumatic disorders came to sharp focus since human behaviors are often predicated or linked to psycho structural social stress disorders and conditions which more often run out of human control, endingin violent and miserable human crimes which further compounds the situations. 


\section{Methodology}

a) Source Materials: relevant literature in Bio-medicine, Theology, Philosophy, Sociology, Psychology and geriatryetc were consulted.

b) Data Analyses: field work to collect, collate and analyze relevant data for statistical interpretation was hindered by limitations of manpower, accessibility of professional, suicidologists and infrastructure shortcomings.

\section{Definition of Terms}

1) Suicide: Simpson and Weiner (1989) defined suicide with its etymology from the Latin "sui", i.e. (of ones self) and "cidium" which means to kill. Hence suicide means self-killing, or to kill oneself. Thus, the question "What is it that could prompt one to kill oneself?"

2) Psychocosmic: Psychocosmic coined by this author from the Greek "Psuche" (i.e. soul or inner life) and cosmos, which means worldliness, mundane and the world in its totality, opposed to the Ecumene (i.e. spiritual world) (See Metzger, 2001, also Aland \& Newman, 1983) etc.

3) Misery: The English "misery" is from the Greek, "miseo" which means to despise, hate, disregard or relegate (See Aland \& Newman, 1983: p. 117) this which entered English as human suffering.

\section{Objective of the Study}

The study primarily aims to press home the point that human miseries and traumatic conditions often influence the human mind or psyche to contemplate suicide, (self destruction) or transferred agitations and violence on society. In other words, management of stress, trauma and other debilitating human social conditions could hold the key to effective monitoring and psychosocial interventions in manic-depressive and genetic suicidal behaviors.

\section{Focus of the Study}

This study analyzes psycho structural build-ups to suicidal behaviors in man. Thus the literature analysis is a citation of scholarly and professional views on the subject matter.

However the scope remains largely dynamics in the psychosocial and sociobiological developments of suicidal behavior.

\section{Problem of This Study}

Not many thinkers and scholars have written on trauma and misery from philosophical reflections, this which clearly reveals that philosophy is yet to realize that it has to constantly ruminate on how to resolve human problems conditions, rather than engaging in frivolities and trivial dialegetos (i.e. senseless linguistic arguments).

\section{Literature Analyses}

\section{Definition and Biochemistry of Suicide}

Suicide was transliterated from the Latin word Suicidium or Suicidia. "Sui" is of onself while "cide" is either killer or slayer. Hence, from the Latin Suicidium we got the word "Suicide" which is currently defined as one who dies by his own hand; slayer or killer of one self. It is an act of self killing, or taking one's own life. Anyone who has killed himself or herself is also referred to as a Suicide.

Simpson and Weiner, even went ahead to bring in elements of highly dangerous military operations into the definition of suicide. Such missions are mainly rescue and commando operations, and are at times tagged "suicide missions" because of their dangerous nature.

Kuper and Kuper (eds., 1996) like a number of other writers, classified suicide into direct and indirect suicides. Direct suicide involves hanging or shooting one-self, while indirect suicide can be in the form of hunger strike and refusal of life-preserving medication.

Hunger strike shows that the individuals have not taken steps necessary for the preservation of their lives; not taken it that hunger strike is being advocated as either direct or indirect suicide. Harran, in discussing religious- 
ly-motivated suicides distinguished between martyrdom and actively terminating oneself. There was also distinction between altruism as an ethical responsibility for honor, and certain customary suicides seen as duties or punishment, and self-sacrifices which are common among the orients like the Buddhist Monks, Gains, Taoist Sages and Confucian gentlemen. The Christian Church sees suicide as a grievous offence. According to McDonald, this is a traditional Christian view, and one may have to make a connection between this and the Hebrew scripture which says, "Thou shall not kill” (Exd. 20:13). This view corresponds to the Islamic proohbition of Katl, i.e. taking human life of all sorts (Q. 25:68). In Islam, there is an emphasis on not killing a believer (Q. 4: 92). Thomists define suicide as an act contrary to the natural law of self preservation. Kane says that Catholicism condemns suicide except in certain situations like the unsound mind and idol worship. This is similar to the Jewish suicide undertaken to avoid the three cardinal sins which are murder, adultery, and idol worship. For Scrutton, suicide lies at the extreme end of depression. Roth's Encyclopedia Judaica says that suicide is a denial of the doctrines of reward and punishment. It also denies the world to come and the sovereignty of God. Though suicide is nowhere explicitly forbidden in the Talmud, post-Talmudic authorities view it as a most heinous sin worse than murder and must be differentiated from martyrdom such as that at Massada (73CE).

Sociological definitions of suicide are linked one way or the other to Durkheim's Le Suicide of 1897. Giddens et al. sees self-killing as the outcome of disturbances in the relationship between society and the individual.

Implicated in this disturbance is the obvious lack of societal cohesion and bonds that have led to egoism and anomie. The psychosocial definition of suicide is psychological, biological and with Freudian ideas. These are attributions of suicidal behavior to despair, hopelessness, helplessness, misery, and other social inequalities.

Psychology sees potential suicide in maladaptive social deviants, while neurology studies this abnormal psychology. Neurology agrees with psychology that suicide is an outcome of depression. A biochemical explanation for depressive-psychoses was offered more than three decades ago, and has been confirmed by modern neurology (see Ackerman, 1992) which attributes depression to a pathological state called the dysfunction of the neurotransmitters of the central nervous system. Sociological Medicine defined suicide as deviant behavior. As already noted, sociology labels suicide as deviance, and the neurosciences have gone on to pull suicide into the realm of medicine. In other words, medicine is being expected to help check all acts of deviance. Medical sociology has a number of intervention strategies, directed towards the client in crises. Early stoic philosophers and David Hume held suicide to be the desire to eliminate a miserable "self" rendered worthless by suffering.There are also forensic definitions of suicide, though we need not spend time on them, since they are likely to appear again under psychological and biological correlates in suicide. Noguchi in "Forensic Medicine", sees suicide as a sudden, unnatural and an unexpected death. Campbell, and Ogiamien interpreted forensic medicine to mean that point at which medicine and law meets. It is called Medical Law or Medical Jurisprudence. Here, the laws that guide medical practice are specified (Ogiamen, 1993).

In forensic medicine, there is a medical examiner (or Chief Medical Officer) whose duty it is to investigate suicidal, homicidal, and accidental deaths. In countries where suicide still remains a criminal offence, the forensic officer prevents suicides since the state has the duty to protect the lives of its citizens. He does this through some laws called paternalism, which curtail the extent to which individuals unnecessarily expose themselves to such dangers like tobacco smoking, alcoholism, risky and self destructive behavior, riding without helmets or driving without seat belts. Forensic experts have had to define suicide in line with psychiatric and neurological discoveries. These discoveries reveal that certain forms of suicide are caused by mental illness. Hence, a forensic psychiatrist will always do well to advise a law court to compulsorily hospitalize a mentally distressed individual since the person is deemed to be a danger to the public and a danger to himself. From this point of view, we now proceed to the Nigerian Constitution which holds human life in very high esteem. This life in question is believed to be in the custody of state and must not be terminated unduly. Hence, sections 326 and 327 of the criminal code, Laws of the Federation of Nigeria 1990, define suicide as a felony, a criminal offence punishable by imprisonment for life.

Section 326 of the Constitution (1999) states that; Any person who-

(1) Procures another to kill himself; or

(2) Counsels another to kill himself and thereby induces him,

(3) Or aids another in killing himself; is guilty of a felony, and is liable to imprisonment forlife.

Section 327, states that:

Any person who attempts to kill himself is guilty of a misdemeanour, and is liable to imprisonment for one year. 


\section{Three Way Definition of Suicide}

Barnhert (ed) and Simpson and Weiner represent the fundamental definition of suicide. They defined suicide as that act purposely and willingly undertaken by an individual with the sole aim of destroying his or her life. This can be done by means of shooting, drowning, poisoning, hanging or stabbing one self etc.

The passive definition includes related acts of dangerous behavior like stunting, rejection of medication, and risk taking acts. This group, (including some gerontologists) says that suicide also involves various forms of risk-taking and deliberate acts which are not geared towards preserving one's own life, (e.g. avoiding medication, excessive fasting etc.). Augustine also pointed an accusing finger at some women who threw themselves into a river which they knew would certainly drown them. Augustine had said they were running away from persecution. The third definition of suicide is on factors which go beyond human control. These include mental imbalance, certain demonic possessions, inherited (genetic) psychotic states etc.

This aspect also qualifies to be called suicides but cannot be tagged "on purpose", hence one wonders what God is likely to do with a suicide who was prompted to it by insanity. However, we may not venture far before finding an answer to that because Montesquieu and Rousseau already gave us an answer to that. Rousseau had made passing comments on the need to consider causes of suicide. But this study goes beyond emphasizing motives in suicide by proposing ethical criteria for suicide. Rousseau was even more interested in what causes the madness that is in suicide (Ogundu, 2000). Finally, Kuper and Kuper (eds., 1996) defined suicide as the death of a person, that is the result of behavior undertaken by that person in the knowledge or expectation of that result. By this definition, we now know that scholars tend to modify and improve on definitions of concepts and acts. This very recent definition of suicide no doubt very well implicates risk-taking in suicide, while it excludes psychotic suicides.

\section{Proposed Redefinition of Suicide}

Our definition of suicide show that one can willingly and unwillingly cause his own death through despair or insanity (Hutchins, 1960).

The assumption is that if one had his mental balance, he would not have killed himself. One thus realizes the element of "willingness" and "unwillingness" in the definition of suicide. On this basis rests an inclination of self-preservation. This willingness factor is also what creates a distinction between willingly killing oneself due to social pressures, or willingly keeping oneself alive despite sufferings. This factor shows that any sane man who intends staying alive will do everything possible to keep himself alive, no matter the misery. However, if he soon exhibits risky and self-destructive behavior, it becomes a case of a premeditated unwillingness to keep on living. This willingness to die lingers between singularly killing one self, or willingly dying by the hands of someone else as in altruism. A redefinition of suicide should lie in this area.

\section{Causes of Suicide}

The illustration table on causes of suicide has five major divisions. The various definitions of suicide show that self killing has many causes. The religious definition depicts that the religious causes of suicide are not the same as the pyschobiological diagnosis of self-killing. So, with as many definitions as there are on self-destruction, in like manner, there are correlate causes. A diagram has been used to illustrate the causes of suicide. It is hoped that this would enhance a better understanding of correlations in the definitions and causes of suicide (Figure 1) (see Ogundu, 2000 Philosophical and Religious Analyses of Suicide).

Various causes of suicide add up to a psychosocial common pathway. This psychosocial pathway means that all suicidal behaviors arise from one social demand or the other, including the religious motivations. These societal elements generate diverse influences on the human psychological state, triggering off deviant actions and various effects of social pressures on the human psyche. In other words, no matter the cause of suicide or suicidal behavior, it must have a psychosocial origin (Atkinson, 1990).

Man is an integral part of a society of inequalities, and individual endurance capacities vary (Hutchins, 1960).

In this section, we want to basically show that certain religious doctrines and practices call for altruistic, ritualistic and salvific motivated suicides; for example, a Jew is allowed to commit suicide to avoid being forcefully converted to another religion, or to avoid capture, adultery, murder, idol worship and so on. Also, Buddhist, Jain ascetic and Japanese Samurai can commit suicide as marks of honor and in expectation of heavenly rewards in the hereafter. 


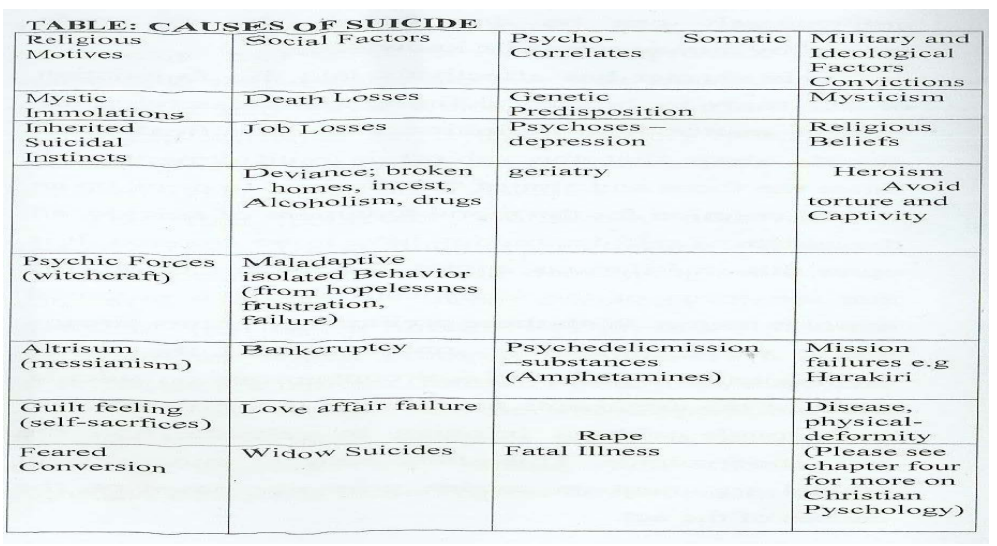

Figure 1.Causes of suicide. Ogundu, 2000, Ibadan Ph.D. Thesis.

There are some random opinions that demonic possessions can lead to self-destruction. In-fact, and importantly, some traditions believe that it is very unnatural for one to terminate himself.

Hence, if it is ever said that someone killed himself, then it could have been due to witchcraft or a spirit possession. Madness and demonism retain some similarities. This belief in a suicide caused by psychic forces cuts across Africa, Europe and Asia. Hobbes talked about it in his Leviathan. The Azande, Ibo and Yoruba also corroborate this assertion.

One area of interest is the Rhodesian angle where suicide was being prescribed as punishment for witchcraft. The Indo-Asian subcontinent had in the past prescribed suicide as penance for those involved in burials for suicides. In like manner, we also note the Socratic episode of Socrates been sentenced to the Hemlock (i.e. death by poisoning) i.e., he was to drink the poison himself. These cases were situations whereby suicide was instituted either as capital punishment for heinous offences or as purification from defilements. But one wonders how heinous such offences were, and how corrective the suicides prescribed turned out to be. Also, it is difficult to understand how, sanctifying, suicide will be for the defiled.

Among the Lugbara, unexpected deaths are attributed to witchcraft. They tend to link demonism and witchcraft to suicide. Crawford's studies on witchcraft and some other works on psychical forces have shown that it is not impossible that some unwilling but possessed persons kill themselves. Suicide prescribed as punishment for accused cases of wizardry was not new in Rhodesia. Crawford has a long list of homicides of which about eleven cases of suicides were recorded. Only about two cases of suicide prescribed as punishment were recorded. A person inflicted with "epe" (i.e. curse) or bad magic could become insane or commit suicide. This is a Yoruba belief which is often taken seriously despite the enormous Christian influence in the area. An Azande will tell you, "So and so was bewitched and killed himself". This outright belief in witchcraft in motivations to suicide has been further buttressed by the Hungarians. Part of the Hungarian tradition was to bury at the cross roads suicides who supposedly died under the influence of a witch or demon. This account by Newall, (2000) came from an European past hugely eroded by Satanic practices and beliefs in magic.

Hobbes attributed suicides of Grecian Maidens to the Furies or Phoebus (i.e. the gods and demons). He called suicides madness. Europeans have always had strong belief in spirit forces; In fact more than Africans, they seem to have had strong traditions of psychic forces. The above metaphysical factors are currently being corroborated by the neurosciences which now attribute suicide to mental illness. Metaphysical protagonists say this madness is inflicted by witches (Neurologists disagree with this) and that of demons, but neurology has ceded insanity to a dysfunction of the neurotransmitters in the human brain.

\section{Durkheim's Theory of Sociological Factors}

Durkheim studied thousands of suicide cases to demonstrate his theory that a person commits suicide due to social demands. The clue he says lies in crucial social facts, breakdown of social solidarity and society where traditional values and bonds have been broken by new (scientific) ideas. Durkheim's sensitivity to the major problems of suicide went back to his work on the Division of Labour and its critique of utilitarianism. The utilitarian claim was that an increasing division of labour and the resultant economic progress would be accompanied by increasing "happiness". Durkheim was however, struck by the fact that the economic progress of newly indu- 
strialized societies was everywhere accompanied by a rise in suicide rates. This was clearly an irony from the point of view of the utilitarian theory. Acting on this observation, Durkheim produced his epic theoretical construction in the classic Monograph Le Suicide (1897). He said that dependence structure in division of labor creates unity and common good, which however, proved wrong when rampant suicides rocked an industrial age. Ironically, it was this division of labor with its resultant industrialization that brought about high incidence of suicides. This theory was carefully broken down in his discussion of anomic suicide.

Anomic Suicide: The individual's needs and satisfaction have always been regulated by society. Each person is a member, or expected to be a member of the singular collective institution called "society". This society is often represented by specific units of society.

The destruction of these societal units and their bonding roles leads to individuation, loss of values, immorality etc. Durkheim believes that free enterprise, search for knowledge, division of labor, science and technology, led to industrialization. These new paradigms in life inevitably shattered the traditionally regulated, integrated and collective conscience known as society. The individual was now exposed to new ideas and living standard brought by democracy, capitalism, and technology. These new trends exceeded the individual's control, culminating in increased crises, stress, drug abuse, alcoholism, industrial crisis, juvenile delinquencies, etc. The individual in a confused and lawless industrial age became confused, and traumatized, thus generating neurotic problems and other psychotic states associated with suicides.

Egoistic Suicide: As already noted, new ideas and inventions brought about industrialization through the division of labour. These advancements in knowledge negatively affected the existing bonds of traditional systems. The emerging individuation and nuclear family systems aided by societal anomie i.e. confusion and lawlessness, led to egoistic suicides. Durkheim says these new ideas and knowledge were occasioned by the protestant ideals which favored the search for knowledge.

Altruistic Suicides: This is a selfless, willful, self destruction for the common good. Messianism falls into this group. Altruists really do not actively kill themselves; rather they willingly stake their lives with the aim of hoping that the sacrifice of one life would be able to return sanity to a chaotic situation. Socrates may not be called an altruist, but when he was falsely charged with sedition, he willingly accepted to drink the hemlock if it will ensure the peace of society.

Durkheim wrote that when a person kills himself in all these cases (i.e. when his master or husband dies), it is not because he assumed the right to do so, but, on the contrary because it is his duty.

Fatalistic Suicide: This form of suicide is caused by excessive regulation and ambitions often frustrated. It also includes passions because it is his duty.

\section{Motives in Sociological Causes of Suicides}

If men kill themselves, it is always a consequence of an event or under the influence of a condition arising from outside or inside. These conditions frustrate their expectations, separating them from those expectations, separating them from their goals, social environs, and unbearable feelings of solitude.

Such a person, according to Halbwachs, has ceased to be integrated into the social bond. When those individuals kill themselves, it is for hatred of society, or someone who represents society, or the agent of his frustration. To kill oneself for a wrong done one, could be a protest, or better still a repressed emotion which found an escape through suicide. But can we really call it an escape, and does self-destruction right that wrong?

\section{Depression in Suicide: Psycho-Biological Correlates}

Psychobiology involves the study of the central nervous system in relation to the effects of psychotropic drugs on the human brain. In the case of suicide, distorted chemical properties of the brain which are connected to psychoses (i.e. depression) are isolated and studied.

Suicide has always been regarded as a component of depressive disorders and despair. Mann and Stanley say that today, it is a recognized component of many non-depressive psychiatric syndromes involving genetic, psychobiological, psychosocial and drug related factors.

The biochemistry of the brain shows that elements like serotonin, dopamine, nor epinephrine etc. are linked to psychotic conditions. Depression is a mood disorder generated by Neurochemical dysfunctions in the brain. Depression itself originates from maladaptive behavior which in general is a psychological response to social factors (see Durkheim's sociological interpretation).

Atkinson et al, restated the fact that depression is a normal response to many of life's stresses like failures (e.g. 
at school) job loss, loss of loved ones, illness, aging, frustrations etc. They however, reiterated the view that in most instances, the disastrous consequence of depression is suicide.

Genetic Causes: Some children are known to have inherited elements of their parents psychotic states. Schilder has a record of child suicidal pre-occupations which show that a child exhibits psychological inadequacies evident in his parents or one of them. Those parents with suicidal instincts pass the instincts on to their children.

Diseases and Physical Deformity: Lahey and Ciminero noted that physical deformity and disease lead to misery. Being blind or crippled are not mean conditions, and stoicism would always prescribe suicide.

Fatal Illness: Irreparable conditions often precipitate suicidal preoccupations. To be fatally ill means to have a medical condition with no hope of cure. There is thus always the possibility that a fatally or terminally ill would contemplate suicide when other angles such as euthanasia and deliberate risk taking behavior fail.

Drug Related Causes: Narcotic drugs including amphetamines and steriods (especially for sports) could cause suicidal behavior. Mann and Stanley cited complex cases of drugs implicated in suicidal acts. Also linked to these drug cases are the effect of hopelessness, deviance and alcoholism. The deviant behavior acts as indicators of eventual suicides. Postmortem studies of suicides by forensic experts often reveal the presence of drug related substances like hallucinogens.

\section{Military Factors in Suicide}

By becoming a soldier, a man obviously does not intend to undertake acts possibly able to lead him to suicide, but part of his military duties may include activities capable of putting his life in danger. These activities of course include warfare, and rescue missions. A soldier knows that his vocation demands his life at any time due to its conflict-prone nature, and the solider having understood the nature of his work must be prepared for death at any time. Unlike in cases of Mountain climbing, excessive austere penance or even hunger strike, he is not knowingly putting his life in danger, he is doing service to father land. But then the mountain climber is after all adventurously ambitious, while those engaged in hunger strike and penance have goals which perhaps may be going too far in trying to achieve a point not requiring such austere level (Nault, 2000).

Though Jesus had enjoined his disciples to fasting and prayer for the attainment of certain goals, he, like the Buddha, did not enjoin fasting unto death. In this vein, military service can be seen more as an altruistic venture aimed at the defense of a greater whole, while penance for atonement or political reasons, in most cases, affect only the individual and perhaps fewer people; yet it can involve a whole nation when one does penance for the deliverance of a nation or take to hunger strike to achieve political freedom for some ethnic groups. Most military suicides had involved reputation and pride. A Samurai warrior of Japan, often killed himself when he loses in battle. He obeys the Samurai Code of honorable death through suicide (Harakiri: Also the Sepukku) than return defeated to his feudal lord. The epitome of this military heroism manifested itself fully in ancient Rome. The earliest example of this military suicide of defeated Roman generals were Cato Marcus Porcius the younger (95-49 BC) his nephew Decius Brutus (d. 42 BC) Curio (49 BC) Cassius (42 BC) and Mark Anthony and Cleopatra (30 BC). The Yoruba had a tradition of overlapping political and military suicides. There is this tradition that a defeated Balogun, (general) preferred to die than return to a shameful welcome. But the strongest traditions are those recorded by Smith and Johnson. According to Smith, a rule or law during Ojigi's reign (1730's $\mathrm{CE}$ ) was that the Aremo (the Alaafin's eldest son) must take poison on the Alaafin's death (i.e. the king's death) to protect the local Obas and their officers from the possible military and political ambitions of an Aremo.

By the same token an Alaafin who falls out of favor with his subjects could be forced (by the traditional council) to kill himself since society cannot afford a deposed Alaafin living while another Alaafin is on the throne. Obviously, there are records of some Biblical Military Suicides. King Saul killed himself at about 1005BC after a Philistine Victory. Zimri lost a decisive battle to Omri in Tirzah. He burnt the King's palace and himself (1 King 16:18). While Samson's suicide is not to be termed military, it nonetheless looked like it. He killed many Philistines in battle, but they later captured him. To escape his continued torture in captivity, he pulled down the pillars of a building and the very heavy stone slabs crushed him and his captors to death (Judges 16:28-31).

\section{Brief Statistical Data Analysis of the Study}

In relation to No 4 above (Table 1), Hindu and Buddhist thoughts were highly ascetic, altruistic and ultimately 
Table 1. Multi-disciplinary views on suicide.

\begin{tabular}{ccc}
\hline Philosophical views & Theological position & Psycho-biology \\
& Suicide can be bewitchment i.e., of evil & (a) Suicide can be linked to \\
Spirit; or of martyrdom. See second & World War Japanese Kamikaze, i.e. \\
suicide Jet-fighters. See Roth (1970) & $\begin{array}{c}\text { Neuro-transmitters of the human brain. } \\
\text { (b) Suicide can also be genetic. } \\
\text { See Mann \& Stanley, 1984. }\end{array}$ \\
\hline
\end{tabular}

self-destructive. See Kawabata Yasunari in Winternitz's Sacred Books of the Ancient East cited by Ogundu (2000) i.e. in A Philosophical and Religious Analyses of Suicide.

\section{References}

Ackerman, S. (1992). Discovering the Human Brain. New York: Academy of Science.

Aland, K., \& Newman, B. (1983). The Greek New Testament and Lexicon. Stuttgart: IBS.

Augustine, A. (Saint) on Suicide, see City of God, cited by Ogundu, C.O., 2000.

Barnhert, R. K. (Ed.) (1995). World Book Dictionary (p. 2094). Chicago: World Book.

Constitution of the Federal Republic of Nigeria (1990/1999).

Crawford, J. R. (1967). Witchcraft and Sorcery in Rhodesia. Appendix 1, London: Oxford Press.

Giddens, A., Sociology of Suicide; see Durkheim’s “Le Suicide”, 1897 cited by Ogundu, C.O., 2000, Ibadan, pp. 1-42.

Hutchins, R. (1960). Great Books of the Western World. Chicago: Britannica and Benton. "Kant on Suicide, "Hobbes on Leviathan".

Johnson, S. (1921). History of the Yoruba's, from the Earliest Times to the Beginning of the British Protectorate. cited by Dr. O. Johnson. Lagos: SCM, pp. 70, 171.

Kuper, Ad., \& Kuper, J. (Eds.) (1996). The Social Science Encyclopaedia (2nd ed., p. 856). London: Routledge.

Mann, A., \& Stanley, M. (1984). The Psychobiology of Suicide. Cited by Ogundu, C.O., Ibadan Ph.D. Thesis, 2000.

McDonald, J. I. Dictionary of the Christian Church. New York: Theologica.

Metzger, B. (2001). The Greek New Testament Lexicon (pp. 70-85). Illinois: Baker.

Nault, W. (Ed.) (1990 and 2000). World Book Encyclopaedia: Vol. 5. Chicago World Book and Fertzer. "Durkheim’s Le Suicide" and "Pseudo-suicide".

Ogiamen, T. (1993). Laws Relating to Medical Practice. In E. Oriakhi (Ed.), The National Medical Directory. Lagos: Health Living and NMA.

Ogundu, C. O. (2000). A Philosophical and Religious Analysis of Suicide. Ibadan Ph.D. Thesis, 2000. See Srutton on Depression, Kane on Catholicism.

Schilder, P. (1964). Contributions to Neuropsychiatry (pp. 301-313). Edited by Laureta Benda, New York: International. Roth Cecil: Encyclopaedia Judaica (cited by Ogundu, C.O., 2000).

Simpson, J. A., \& Weiner, E. S. C. (1989). The Oxford Encyclopaedic Dictionary of English. Vol. 19, Oxford: Clarendon.

Thomas Noguchi (1997) Forensic Medicine. In S. Parker (Ed.), Mcgraw Hill Encyclopaedia of Science and Technology (p. 34). Vol. 17, New York: Mcgraw Hill. 